\title{
Comparação do crescimento e produção entre alho proveniente de cultura de tecidos e de multiplicação convencional ${ }^{*}$.
}

\author{
Francisco V. Resende ${ }^{1}$, Rovilson J. de Souza ${ }^{2}$, Valdemar Faquin ${ }^{2}$, Juliano T. V. Resende ${ }^{2}$ \\ ${ }^{1}$ UNIMAR - Faculdade de Ciências Agrárias, C. Postal 554, 17525-902 Marília - SP; ${ }^{2}$ UFLA C. Postal 37, 37200-000 Lavras - MG.
}

\section{RESUMO}

Este trabalho foi conduzido na área experimental do Setor de Olericultura/Departamento de Agricultura da Universidade Federal de Lavras com o objetivo de avaliar o crescimento e a produção de plantas de alho da cultivar Gigante Roxão provenientes de cultura de tecidos (propagação por meristemas), comparando-as com plantas da mesma cultivar multiplicadas de forma convencional. Utilizou-se delineamento experimental de blocos ao acaso em esquema de parcelas subdivididas no tempo, com dois tratamentos (plantas de cultura de tecidos e de multiplicação convencional) nas parcelas e sete épocas de avaliação $(30,50,70,90,110,130$ e 150 dias após o plantio) como sub-parcelas. Foram utilizadas quatro repetições. Em cada época foram coletadas seis plantas/parcela para determinação de matéria seca (parte aérea, bulbo, raízes e total), altura da planta, número médio de folhas/planta e razão bulbar. No final do experimento avaliou-se a produção, peso médio de bulbo e número de bulbilhos/bulbo. O desenvolvimento da parte aérea foi semelhante entre os tratamentos até os 70 dias do plantio, após o qual, as plantas originadas por cultura de tecidos mostraram-se superiores. Aos 110 dias do plantio, as plantas provenientes de cultura de tecidos apresentaram aumentos significativos de $29,0 \%, 80,3 \%$ e $145,0 \%$ respectivamente, na altura e produção de matéria seca da parte aérea e de raízes em relação às plantas convencionais. As plantas de cultura de tecidos também foram superiores, aos 150 dias do plantio, com $68,2 \%$ e $67,0 \%$ a mais de matéria seca do bulbo e total, respectivamente. Verificou-se um prolongamento de cerca de 13 dias no ciclo cultural das plantas de cultura de tecidos em relação às convencionais, causando atraso na formação dos bulbos, de acordo com o comportamento da razão bulbar. Para peso médio de bulbo e número de bulbilhos/bulbo, as plantas de cultura de tecidos foram, respectivamente, 109,5 e $37,0 \%$ superiores, resultando num aumento de $99,8 \%$ na produção de bulbos.

Palavras-chave: Allium sativum, cultivo in vitro, curva de crescimento, produtividade.

\begin{abstract}
Comparative evaluation of growth and production in garlic plants obtained from tissue culture and conventional multiplication systems.

This work was carried out in the experimental area of the Universidade Federal de Lavras, Minas Gerais state, Brazil, with the objective of comparing the growth, development and production in garlic plants, of the cultivar Gigante Roxão grown from tissue culture (meristem-tip culture), with plants of the same cultivar multiplied in a conventional way. The experiment was laid out in a complete split splot randomised block scheme with two treatments (plants obtained from tissue culture and conventional multiplication) in the plots, and seven evaluation dates $(30,50,70,90,110,130$ and 150 days after planting) as sub-plots. Four replications were used. At each date, six plants/plot were collected for dry matter determination (leaves, bulbs, roots and total) and also to evaluate the plant growth characteristics, plant height, number of leaves per plant and bulb growth. At the end of the experiment production, weight and number of cloves per bulb were evaluated. The development of aerial plant parts was similar among the treatments until 70 days after planting, after which time, plants propagated by tissue culture displayed superior growth. The tissue culture plants showed increases in plant height, dry matter of aerial parts and roots in relation to conventional plants, by $29.0 \%, 80.3 \%$ and $145.0 \%$ respectively 110 days after planting. Tissue culture plants also showed a respective $68.2 \%$ and $67.0 \%$ greater bulb and total dry matter 150 days after planting when compared to conventionally multiplied plants. The pseudostalk diameter/bulb ratio indicated that formation of bulbs by tissue culture plants was delayed by 13 days in relation to bulbs from plants multiplied by the conventional way, thus increasing the lifecycle by the same amount of days. For mean bulb weight and number of cloves per bulb, plants from tissue culture once more stood out, showing increases of $109.5 \%$ and $37.0 \%$, respectively, which resulted in an increase of bulbs of $99.8 \%$ in bulb production.
\end{abstract}

Keywords: Allium sativum, in vitro culture, growth curve, productivity.

\section{(Aceito para publicação em 22 de abril de 1999)}

$\mathrm{N}^{\mathrm{es}}$ estes tempos de economia mais estável, o alho tem estado mais presente na mesa do brasileiro, causando um aumento substancial no consumo deste condimento. $\mathrm{O}$ volume de alho comercializado na Central de Abastecimento de São Paulo (CEAGESP) evo- luiu de 2.588 toneladas anuais em 1992 para 4.535 em 1996 (AGRIANUAL, 1998). Entretanto, esse maior consumo não representa uma vantagem efetiva para o produtor brasileiro, devido ao grande volume de importação que atingiu 100.359 toneladas em 1996 (FAO,
1998), somado à concorrência acirrada do produto importado, de melhor qualidade e custo inferior ao nacional.

Embora a cultura do alho tenha evoluído bastante nas últimas duas décadas em função da incorporação de novas tecnologias, o mercado interno vem re-

\footnotetext{
* / Parte da tese de doutoramento do primeiro autor apresentada à Universidade Federal de Lavras (UFLA), Lavras - MG
} 
cebendo a cada ano quantidades expressivas de alho importado principalmente da Argentina e China. A partir de 1993 o mercado brasileiro começou a ser inundado pelo alho chinês, de ótima qualidade e baixo custo. Em 1995, o Brasil importou 85.382 toneladas de alho, sendo $45,5 \%$ desse total proveniente da China (AGRIANUAL, 1998). Entre 1993 e 1996 a importação brasileira de alho cresceu $114,42 \%$ e houve uma redução de 44,70\% na produção nacional no mesmo período (FAO, 1998).

Com o avanço tecnológico dos últimos anos, a produtividade brasileira de alho evoluiu de 4,00 para 4,83 t/ha em dez anos (IBGE, 1998), entretanto, ainda é baixa quando comparada à de países como Argentina (7,57 t/ha), China $(8,67)$, EUA $(12,17$ t/ha) e Egito $(24,47$ t/ha) (FAO, 1998).

A cultura do alho no Brasil ainda esbarra em problemas sérios como agricultores pouco tecnificados, distúrbios fisiológicos, desequilíbrios nutricionais e cultivares pouco adaptadas. A propagação exclusivamente assexuada é outro sério entrave dessa cultura, pois permitiu que patógenos e pragas se disseminassem com facilidade através das gerações de cultivo, causando a degenerescência generalizada dos clones comerciais. Entre os patógenos, destacam-se os vírus, em função do seu potencial de reprodução, facilidade de transmissão, perpetuação na cultura e principalmente pela grande dificuldade de controle.

Tanto no Brasil quanto em outras partes do mundo, tem sido reportado, que grande parte das cultivares comerciais de alho encontram-se infectadas por vírus (Conci et al., 1992; Dijk, 1993. e Dusi et al., 1994). Algumas técnicas de cultura de tecidos vegetais tem sido utilizadas com sucesso na erradicação das viroses do alho (Daniels et al. 1978; Mosella \& Fernadez, 1985; Walkey et al. 1987; Conci \& Nome, 1991), obtendo-se plantas vigorosas e altamente produtivas em relação ao material infectado (Walkey \& Antill, 1989; Garcia et al., 1989 ; Resende et al., 1995 ).

Sabe-se que as células de plantas enfermas concorrem com o patógeno por nutrientes orgânicos e inorgânicos, originando uma série de distúrbios que prejudicam o desenvolvimento satisfatório de seus vários órgãos (Marschner, 1983). Nanismo, amarelecimento em forma de mosaico e redução acumulativa do vigor e da produção são sintomas característicos de infecção viral em plantas (Paiva \& Kitajima, 1985). No alho, sintomas como redução significativa na concentração de clorofila das folhas (Messiaen et al. 1981), número e comprimento das folhas, diâmetro do colo e do bulbo e menor número, tamanho e peso dos bulbilhos (Messiaen et al. 1981; Bhojwani et al. 1982; Hwang et al. 1983; Walkey \& Antill, 1989) são observados com frequência.

Os sintomas viróticos em plantas vegetativamente multiplicadas, são pouco perceptíveis quando não se dispõe de plantas sadias para comparação. Portanto, o estudo comparativo do crescimento, acúmulo de matéria orgânica e produção entre plantas multiplicadas através de cultura de tecidos e pela via convencional pode fornecer um diagnóstico mais preciso dos danos causados pelos vírus às culturas.

Cabe à pesquisa determinar o comportamento em condições de campo, do material isento de vírus, proveniente de cultura de tecidos, visando fornecer subsídios ao produtor comercial quanto às vantagens comparativas da utilização deste material, porém esclarecendo que o verdadeiro potencial destas plantas será conhecido quando aspectos relacionados ao crescimento, produção, absorção, utilização de nutrientes, qualidade, conservação pós-colheita e outros sejam estudados sistematicamente.

A elucidação de algumas destas características relacionadas com o crescimento e produção do alho proveniente de cultura de tecidos comparativamente ao mesmo material multiplicado de forma convencional, foi o objetivo deste estudo.

\section{MATERIAL E MÉTODOS}

Este trabalho foi realizado no Setor de Olericultura do Departamento de Agricultura da Universidade Federal de Lavras, MG. O experimento foi conduzido em um Latossolo Roxo com as seguintes características químicas e físicas após as devidas correções: $\mathrm{pH}=6,4, \mathrm{P}=$ $14 \mathrm{mg} / \mathrm{dm}^{3}, \mathrm{~K}=148 \mathrm{mg} / \mathrm{dm}^{3}, \mathrm{Ca}=41$ mmolc $/ \mathrm{dm}^{3}, \mathrm{Mg}=18 \mathrm{mmolc} / \mathrm{dm}^{3}, \mathrm{Al}=$ $1 \mathrm{mmolc} / \mathrm{dm}^{3}, \mathrm{~V}=75 \%$, matéria orgâni$\mathrm{ca}=35 \mathrm{~g} / \mathrm{dm}^{3}$ e 210,280 e $510 \mathrm{~g} / \mathrm{kg}$ de areia, limo e argila, respectivamente.

Os tratamentos foram constituídos a partir da cultivar Gigante Roxão cedida pela Embrapa Hortaliças oriunda de multiplicação convencional em Brasília, DF. Esta cultivar pertence ao grupo dos alhos semi-nobres (ciclo médio), apresenta bulbos com película de coloração arroxeada, pequena incidência de bulbilhos "palitos", boa resistência ao pseudo-perfilhamento e adaptação às condições de plantio do sudeste e centro-oeste do país dispensando a necessidade de vernalização (EMBRAPA, 1984). Uma parte deste material foi multiplicada in vitro, no Laboratório de Cultura de Tecidos da UFLA, de acordo com a metodologia desenvolvida por Câmara (1988), a partir da regeneração de meristemas com um ou dois primórdios foliares e tamanho entre 0,2 e $0,5 \mathrm{~mm}$ (Quak, 1977), visando a limpeza de viroses. As plantas obtidas deste processo não foram indexadas para viroses.

O plantio foi realizado em 29 de abril de 1995 utilizando delineamento experimental de blocos casualizados e esquema de parcelas subdivididas no tempo com dois tratamentos (plantas provenientes de cultura de tecidos e de multiplicação convencional) nas parcelas e sete épocas de avaliação (30, 50, 70, 90, $110,130,150$ após o plantio) nas subparcelas, com quatro repetições. Os bulbilhos foram classificados antes do plantio, usando-se apenas aqueles retidos nas peneiras 2 (malha $10 \times 20 \mathrm{~mm}$ ) e 3 (malha $8 \times 17 \mathrm{~mm}$ ). As parcelas foram constituídas por canteiros com 0,20 $\mathrm{m}$ de altura, $1 \mathrm{~m}$ de largura e $3 \mathrm{~m}$ de comprimento com cinco linhas de plantio. Os bulbilhos foram plantados a uma profundidade de $5 \mathrm{~cm}$, com espaçamento de $10 \mathrm{~cm}$ entre plantas nas linhas e $20 \mathrm{~cm}$ entre linhas. A área útil da parcela foi definida como as três fileiras centrais, descartando-se duas plantas em cada linha na extremidade da parcela. Obteve-se uma área útil de 1,56 $\mathrm{m}^{2}$, dividida em duas sub-áreas menores: 0,60 $\mathrm{m}^{2}$ (30 plantas/parcela) para avaliações não destrutivas; altura de plantas e número médio de folhas/ 
Tabela 1. Resumo da análise de variância para Altura da planta (AP), Número de folhas por planta (NFP), Matéria seca da parte aérea (MSPA), bulbos (MSB), raízes (MSR), total (MST) e razão bulbar (RB). Lavras, MG, UFLA, 1995.

\begin{tabular}{|c|c|c|c|c|c|c|c|c|}
\hline \multirow{2}{*}{ Fontes Variação } & \multicolumn{8}{|c|}{ Variâncias (QM) } \\
\hline & G.L & AP & NFP & MSPA & MSB & MSR & MST & RB \\
\hline Blocos & 3 & 190,76 & 1,26 & 1,74 & 0,48 & 0,04 & 2,85 & 0,001 \\
\hline Propagação (P) & 1 & $1656,70 *$ & 2,43 & 27,21 ** & $36,84^{*}$ & 0,34 ** & $140,90 *$ & 0,11 ** \\
\hline Resíduo (a) & 3 & 68,90 & 2,31 & 0,71 & 3,92 & 0,004 & 8,20 & 0,001 \\
\hline Idade planta (IP) & 6 & $1553,80^{* *}$ & $67,23^{* *}$ & $41,30 * *$ & $120,43^{* *}$ & $0,25^{* *}$ & $253,4^{* *}$ & $0,23^{* *}$ \\
\hline$P \times I P$ & 6 & $42,88^{* *}$ & 1,67 & $4,21^{\star \star}$ & $9,38^{* *}$ & 0,06 ** & 23,60 ** & 0,01 ** \\
\hline Resíduo (b) & 36 & 10,30 & 0,98 & 0,96 & 1,43 & 0,06 & 4,06 & 0,001 \\
\hline C.V. (\%) & & 6,72 & 15,65 & 31,84 & 36,05 & 35,37 & 30,23 & 9,24 \\
\hline
\end{tabular}

*,** - Significativo ao nível de 5 e $1 \%$ de probabilidade, respectivamente, pelo teste $\mathrm{F}$ de Snedecor .

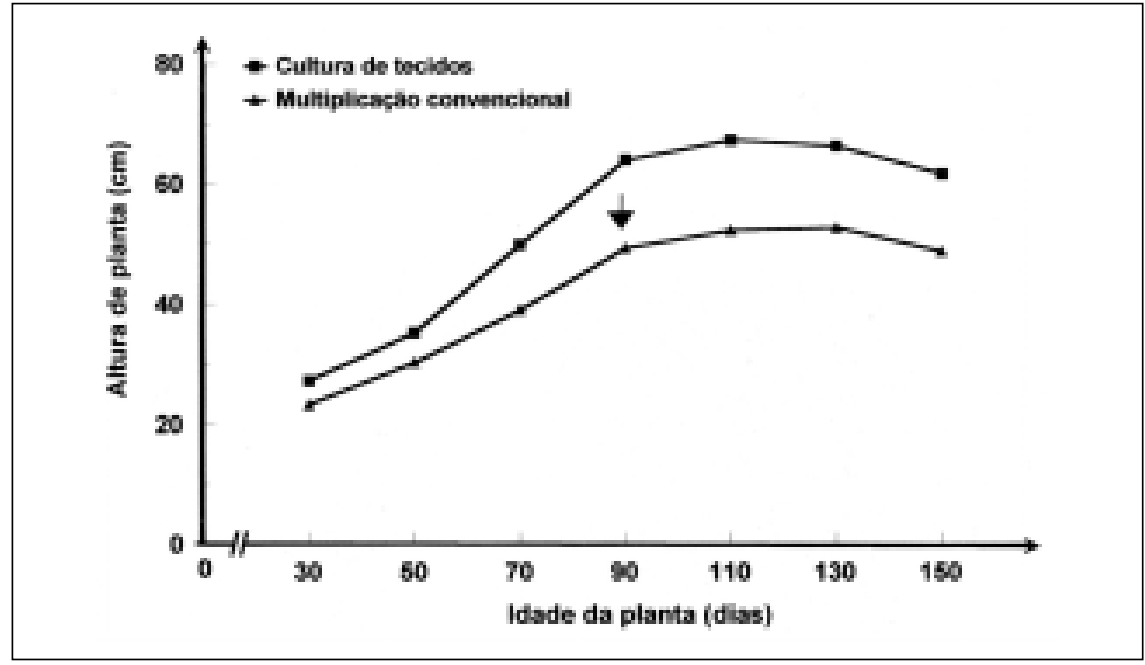

Figura 1. Evolução do crescimento em altura de plantas de alho provenientes de cultura de tecidos e de multiplicação convencional. Lavras, MG, UFLA, 1995. A seta indica a época em que as formas de multiplicação começaram a diferir estatisticamente (Tukey, 5\%).

planta, peso médio de bulbo, número de bulbilhos/bulbo e peso total de bulbos e $0,9 \mathrm{~m}^{2}$ destinada à coleta de plantas para determinação de matéria seca.

A adubação foi realizada de acordo com a análise do solo e as recomendações da Comissão...(1989), constando de $1.125 \mathrm{~kg} /$ ha de superfosfato simples (200 $\mathrm{kg} / \mathrm{ha}$ de $\left.\mathrm{P}_{2} \mathrm{O}_{5}\right), 103,3 \mathrm{~kg} / \mathrm{ha}(60 \mathrm{~kg} / \mathrm{ha}$ de $\mathrm{K}_{2} \mathrm{O}$ ) de cloreto de potássio, $50 \mathrm{~kg} / \mathrm{ha}$ de sulfato de magnésio, $15 \mathrm{~kg} / \mathrm{ha}$ de bórax e $10 \mathrm{~kg} / \mathrm{ha}$ de sulfato de zinco. Foram utilizados $234 \mathrm{~kg} / \mathrm{ha}$ (105 kg N/ha) de uréia parcelados $1 / 3$ no plantio , $1 / 3$ aos $45 \mathrm{e}$ $1 / 3$ aos 70 dias após o plantio.

Os tratos culturais e fitossanitários bem como os demais cuidados com a cultura foram realizados de acordo com as necessidades e as recomendações regionais para o alho.
Em cada época foram coletadas seis plantas/parcela para determinação de matéria seca (parte aérea, bulbo, raízes e total) e avaliadas características do crescimento da planta como: altura, número médio de folhas/planta, razão bulbar. A razão bulbar proposta por Mann (1952) expressa o grau de desenvolvimento do bulbo, através da relação diâmetro do pseudocaule na altura do colo/diâmetro da parte mediana do bulbo.

A colheita dos bulbos baseado na senescência da parte aérea, foi efetuada com 157 dias de idade, para plantas convencionais e 170 dias para plantas provenientes de cultura de tecidos. Os bulbos foram submetidos a um período de cura por 50 dias, avaliando-se em seguida o peso médio de bulbo, número de bulbilhos/bulbo e peso total de bul- bos/parcela, transformado para produção em t/ha.

Os dados foram testados quanto à normalidade e homogeneidade pelos testes de Bartlett e Lilliefors seguindo recomendações de Little e Hills (1978) antes de se proceder à análise de variância. As médias foram comparadas pelo teste de Tukey ao nível de 5\% de probabilidade.

\section{RESULTADOS E DISCUSSÃO}

A análise de variância indicou efeito significativo da forma de propagação, idade da planta e da interação entre estes fatores para todas as características de crescimento avaliadas, com exceção do número de folhas por planta (Tabela 1).

$\mathrm{O}$ crescimento das plantas em altura, foi lento até 50 dias de idade, aumentando a partir deste ponto até atingir o máximo aos 110 dias após o plantio (Figura 1). Este período foi seguido por leve e gradativo decréscimo, indicando o início dos processos envolvidos na senescência da parte aérea. Este padrão sigmóide de crescimento (Salisbury \& Ross, 1985) foi observado nas plantas provenientes das duas formas de multiplicação.

A fase de crescimento mais intenso foi verificada entre 50 e 90 dias após o plantio. Trabalhos mostram que o crescimento do alho nas condições brasileiras, intensifica-se por volta dos 60 dias até 120 dias após o plantio (Oliveira et al., 1971; Ferreira, 1972; Fontes, 1973; Silva et al., 1981).

A altura das plantas das duas formas de multiplicação foram semelhantes até 
os 70 dias do plantio; após o qual passaram a diferir estatisticamente até o final do ciclo (Figura 1), atingindo crescimento máximo aos 110 dias após o plantio. Neste ponto a diferença entre os tratamentos atingiu $15 \mathrm{~cm}(29 \%)$ a favor das plantas oriundas de cultura de tecidos. A altura superior das plantas de alho oriundas de cultura de tecidos em relação às provenientes de multiplicação convencional tem sido verificada em diferentes épocas ao longo do ciclo cultural, como constatado em vários trabalhos (Carvalho et al., 1981; Hwang et al., 1983; Walkey \& Antill, 1989 e Resende et al., 1995).

Observou-se um rápido aumento do número de folhas em atividade na planta até 110 dias após o plantio, decrescendo a partir de então (Figura 2). Não foram observadas diferenças significativas no número de folhas vivas entre as formas de multiplicação ao longo do ciclo, com exceção de 150 dias após plantio, onde as plantas convencionais em função de adiantada senescência, mostraram-se significativamente inferiores às provenientes de cultura de tecidos para esta característica. Existem referências (Hwang et al. 1983; Resende et al., 1995) indicando que plantas oriundas de cultura de tecidos apresentam pouca ou quase nenhuma variação no número de folhas em relação às plantas convencionais, e que o aspecto vigoroso das plantas isentas de víroses manifesta-se mais pela altura da planta, largura das folhas e incremento na concentração de clorofila (Messiaen et al., 1981; Hwang et al., 1983; Walkey \& Antill, 1989) do que pelo número de folhas em atividade. O número de folhas vivas começou a decrescer a partir dos 110 dias após o plantio, em ambas as formas de multiplicação. Esta situação apresenta-se como um indicativo de que a planta encontra-se na fase final do crescimento vegetativo, sendo acompanhada, além da gradual senescência foliar, pela paralisação do crescimento da planta em altura e intensificação do crescimento dos bulbos (Mann, 1952; Bertoni et al. 1992).

$\mathrm{O}$ acúmulo de matéria seca em todas as partes da planta foi reduzido até os 70 dias de idade, para ambas formas de multiplicação (Figura 3). Na parte

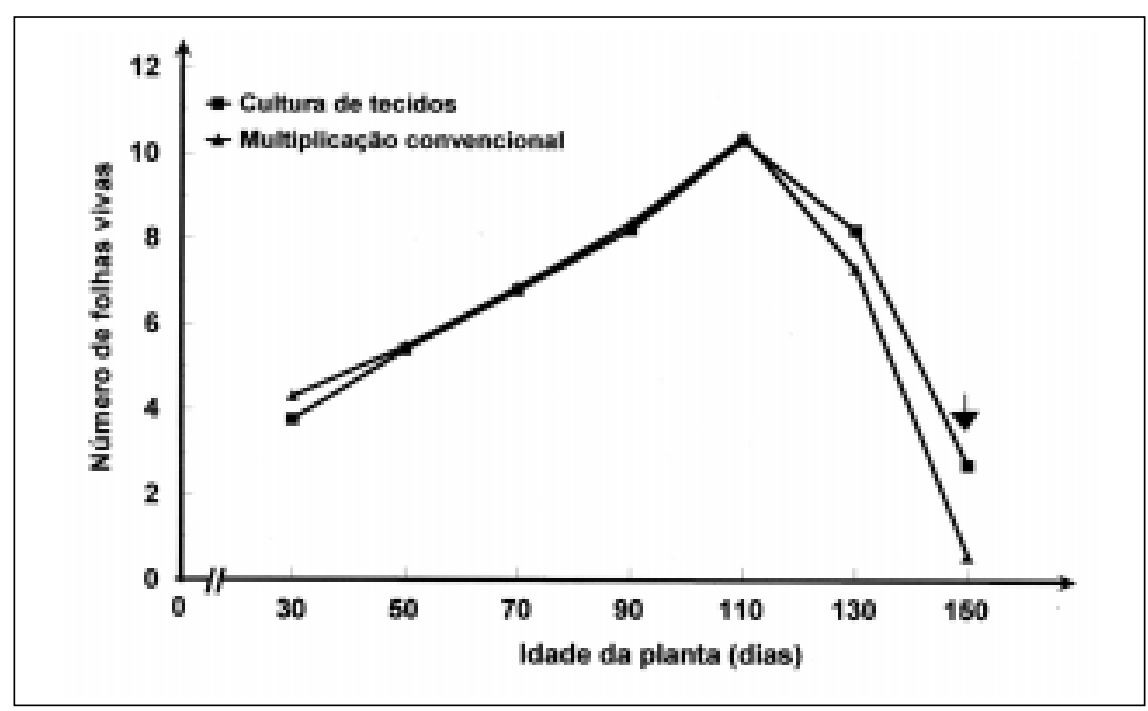

Figura 2. Evolução do número de folhas vivas (fotossinteticamente ativas) ao longo do ciclo da cultura, em plantas de alho provenientes de cultura de tecidos e de multiplicação convencional. Lavras, MG, UFLA, 1995. A seta indica a época em que as formas de multiplicação começaram a diferir estatisticamente (Tukey, 5\%).

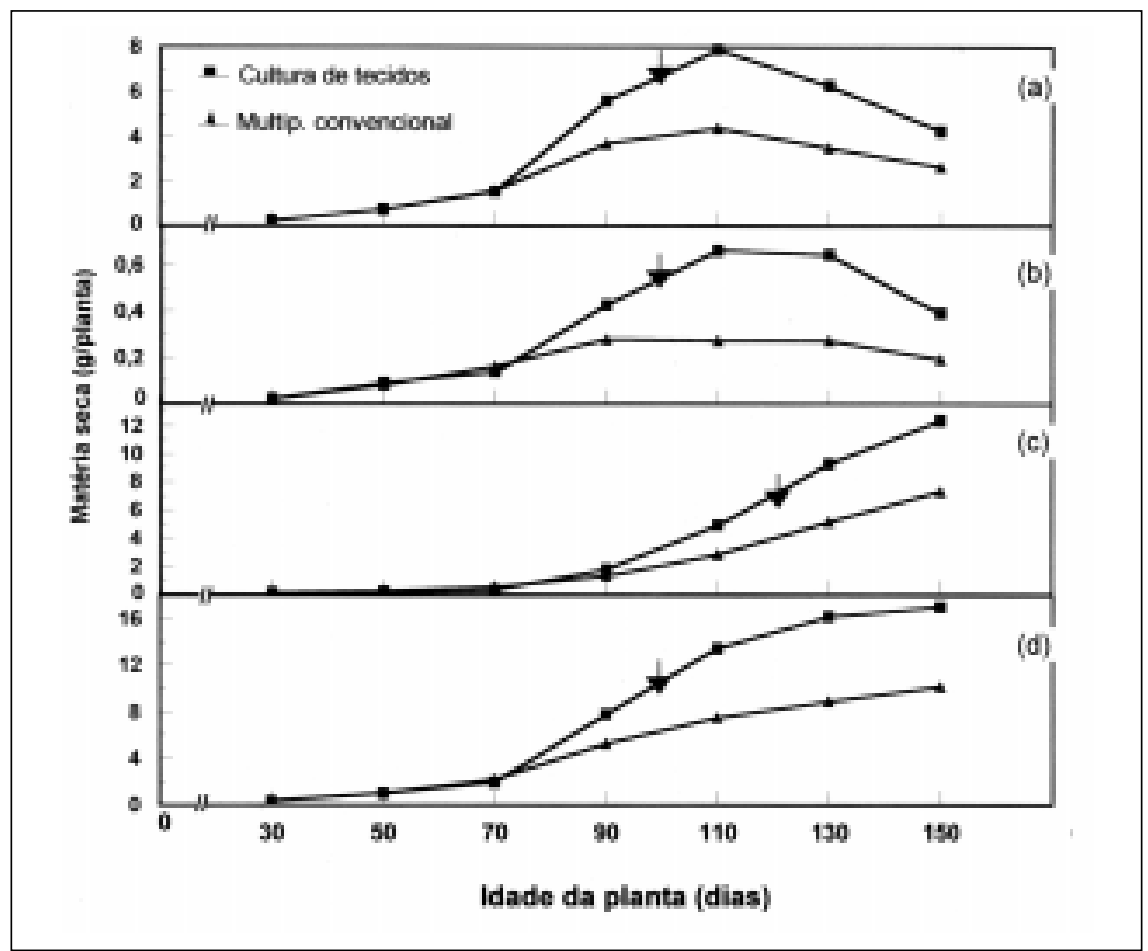

Figura 3. Matéria seca da parte aérea (a), raízes (b), bulbos (c) e total (d) de alho proveniente de cultura de tecidos e multiplicação convencional, durante o desenvolvimento da cultura. Lavras, MG, UFLA, 1995. A seta indica a época em que as formas de multiplicação começaram a diferir estatisticamente (Tukey, 5\%).

aérea e no sistema radicular (Figura 3a e 3b), a matéria seca acumulou-se intensamente a partir dos 70 dias atingindo seu máximo aos 110 dias, coincidindo com a bulbificação significativamente diferente entre plantas de ambas formas de multiplicação (Figura 3c). Após os 110 dias observa-se uma intensa re- dução da quantidade de matéria seca na parte aérea e raízes, atingindo seu menor valor aos 150 dias, que coincide com o maior acúmulo nos bulbos. Comportamento semelhante foi consignado nos trabalhos de Zink (1963), Nogueira (1979) e Silva et. al. (1981) e explicado pelo redirecionamento de grande parte 
Tabela 2. Produção de bulbos, peso médio de bulbo e número de bulbilhos por bulbo de plantas de alho oriundas de cultura de tecidos e multiplicação convencional. Lavras, MG, UFLA, 1995.

\begin{tabular}{|c|c|c|c|}
\hline $\begin{array}{c}\text { Forma de } \\
\text { multiplicação }\end{array}$ & $\begin{array}{c}\text { Produção } \\
\text { bulbos (t/ha) }\end{array}$ & $\begin{array}{c}\text { Peso médio } \\
\text { bulbo (g) }\end{array}$ & $\begin{array}{c}\text { № } \\
\text { bulbilhos/bulbo }\end{array}$ \\
\hline Cultura de tecidos & $16,33 \mathrm{a}$ & 35,45 a & $22,25 \mathrm{a}$ \\
\hline Multip. Convencional & 8,17 & 16,92 & 16,25 \\
\hline C.V. (\%) & 12,02 & 26,18 & 7,42 \\
\hline
\end{tabular}

*/ Médias seguidas de mesma letra nas colunas não diferem entre si a 5\% de probabilidade pelo teste de Tukey.

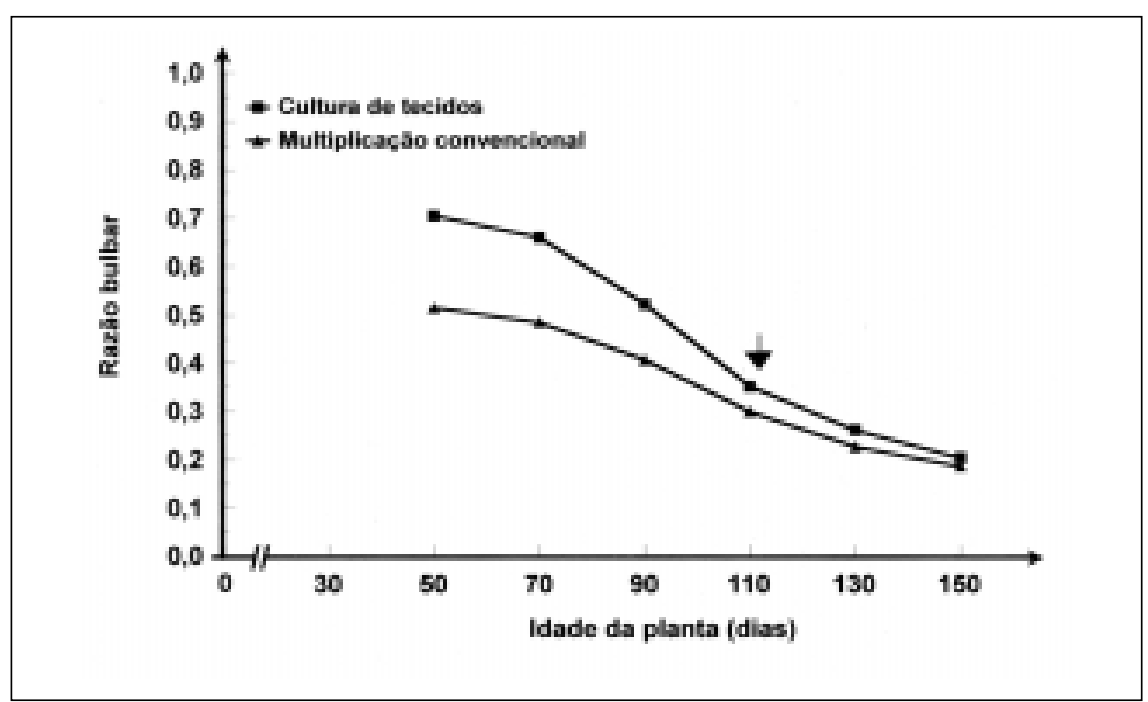

Figura 4 - Razão bulbar do alho em função da idade da cultura, em plantas provenientes de cultura de tecidos e de multiplicação convencional. Lavras, MG, UFLA, 1995. A seta indica a época em que as formas de multiplicação deixaram de diferir estatisticamente (Tukey, 5\%).

dos compostos orgânicos e inorgânicos das folhas e raízes para os bulbos (Werner, 1986).

O acúmulo de matéria seca na parte aérea, raízes e total praticamente não diferiu até 70 dias e nos bulbos até 90 dias após o plantio entre as duas formas de multiplicação. O conteúdo de matéria seca aumentou bruscamente em plantas provenientes de cultura de tecidos, a partir destas épocas, levando ao aparecimento de diferenças significativas em relação a plantas convencionais aos 90 dias para parte aérea, raízes e total e 110 dias para os bulbos (Figura 3).

Em termos percentuais, as plantas provenientes de cultura de tecidos mostraram um acréscimo de $80,3 \%$ no conteúdo de matéria seca na parte aérea em relação as plantas convencionais, aos 110 dias após o plantio. Aos 150 dias foram observados incrementos de $68,2 \%$ nos bulbos e $67,0 \%$ na matéria seca total.
O início da bulbificação indicado pelo decréscimo da razão bulbar foi verificado a partir dos 50 dias para as duas formas de multiplicação (Figura 4). Antes desta época, a razão bulbar tende a crescer, devido a aumentos progressivos no diâmetro do pseudocaule, sem aumento correspondente no diâmetro do bulbo (Ferreira, 1972).

Valores de razão bulbar inferiores a 0,5 indicam formação definitiva e o amadurecimento do bulbo, ou final da bulbificação e ocorrem quando esta relação torna-se menor que 0,2 . De acordo com esta proposta, verificou-se (Figura 3) em plantas originadas por multiplicação convencional, que a bulbificação intensificou-se por volta dos 90 dias após o plantio e o amadurecimento ocorreu aos 150 dias. Em contrapartida, a formação dos bulbos em plantas de cultura de tecidos intensificou-se aos 110 dias e o amadurecimen- to ocorreu após 150 dias do plantio. Entre 50 e 90 dias após o plantio, a razão bulbar das plantas provenientes de cultura de tecidos mostrou-se superior à das plantas convencionais, indicando que o processo de bulbificação das primeiras, como também verificado para a senescência da parte aérea, ocorreu de forma significativamente mais lenta.

Empiricamente, o ponto de colheita do alho baseia-se na senescência completa da parte aérea. Desta forma as plantas provenientes de multiplicação convencional apresentaram ponto de colheita aos 157 dias após o plantio, enquanto as plantas oriundas de cultura de tecidos alcançaram este estágio somente aos 170 dias, prolongando seu ciclo em 13 dias em relação às convencionais. As alterações metabólicas provocadas pela infecção viral estão freqüentemente relacionadas a senescência da planta (Gibbs \& Harrison, 1979), que explicaria, provavelmente, a diferença no ciclo vegetativo entre as plantas das duas formas de multiplicação.

A produção das plantas provenientes de multiplicação por cultura de tecidos mostrou-se significativamente superior à das plantas obtidas por multiplicação convencional, devido ao maior peso médio de bulbo e ao número superior de bulbilhos por bulbo (Tabela 2). Enunciado em termos percentuais, isto significa aumento de 99,8, 109,5 e $36,9 \%$, na produção, no peso médio de bulbo e no número de bulbilhos por bulbo, respectivamente.

Foram verificados comportamentos semelhantes, porém em magnitudes diferentes $(26,0$ e $39,0 \%)$, para o peso médio de bulbos de plantas de cultura de tecidos em relação às multiplicadas de forma convencional das cultivares California Early e Gigante Roxo (Carvalho et al., 1981; Resende et al., 1995). O aumento do número de bulbilhos/bulbo em plantas de alho oriundas de cultura de tecidos depende da cultivar utilizada. Assim, em três clones estudados, observou-se que um deles teve o número de bulbilhos/bulbo aumentado, enquanto nos dois restantes permaneceu inalterado (Graichen et al., 1988).

Tanto no Brasil quanto no exterior têm sido observados desempenhos mais 
modestos, em termos de produção de plantas provenientes de cultura de tecidos em relação ao mesmo material multiplicado de forma convencional. Desta forma, aumentos de $25,0 \%$ e $50,0 \%$ foram obtidos na produção para as cultivares Germidour e Thermidrome livres de vírus, respectivamente (Messiaen et al., 1981). Nas cultivares Rosé du Var, Moulinin e Printanor, verificaram-se reduções de 34,0; 43,5 e 44,0\% na produção de plantas infectadas destas cultivares em comparação com plantas sadias, respectivamente (Walkey \& Antill 1989). No Brasil, encontraram-se diferenças oscilando entre 8,8 e $38 \%$ nas cultivares Lavínia, Chonan, Quitéria e São Lourenço (Garcia et al., 1989). Na cultivar Quitéria verificou-se aumento de produção igual a 48,0\% para plantas de cultura de tecidos em relação à plantas multiplicadas de forma convencional da mesma cultivar (Barni \& Garcia, 1994).

É importante ressaltar que os trabalhos acima mencionados foram realizados na Europa e sul do Brasil com cultivares mais exigentes em temperaturas baixas e fotoperíodo longo para bulbificar. Na região sudeste do Brasil, encontrou-se para a cultivar Gigante Roxo (pouco exigente em baixas temperaturas) acréscimos médios de $63,17 \%$ na produção de clones proveniente de cultura de tecidos em relação à testemunha multiplicada pelo método convencional (Resende et al.,1995). Portanto, as variações relativamente acentuadas nos diferenciais de produção destes vários materiais podem ser atribuídas em parte, aos genótipos com vários níveis de tolerância às viroses (Garcia et al. 1992) e às variações de clima, solo e manejo da cultura entre regiões onde os trabalhos foram conduzidos, pois é sabido que estes fatores podem influenciar as populações de vetores, interferindo na disseminação das víroses (Gibbs \& Harrison, 1979). Portanto, comparações dessa natureza devem ser realizadas sempre que possível com os materiais livres e infectados por vírus procedentes de bulbilhos de um mesmo bulbo e avaliados nas mesmas condições edafoclimáticas.

Nas condições em que foi realizado o presente trabalho, verificou-se que as plantas provenientes de cultura de teci- dos apresentaram crescimento e acúmulo de matéria seca superiores às plantas convencionais, somente no período de maior desenvolvimento da cultura, isto é, entre 70 e 150 dias na parte aérea e 90 e 150 dias no bulbo. Características como o ciclo cultural, peso médio de bulbo e número de bulbilhos/bulbo foram também maiores no alho proveniente de cultura de tecidos, bem como a produção total de bulbos, que foi $99,8 \%$ superior à do oriundo de multiplicação convencional.

\section{AGRADECIMENTOS}

Ao pesquisador João A. de Menezes Sobrinho (Embrapa Hortaliças) pelo fornecimento do alho-planta convencional utilizado neste trabalho. À Coordenadoria de Aperfeiçoamento de Pessoal de Ensino Superior (CAPES) pela concessão da bolsa de doutorado e à Fundação de Amparo a Pesquisa de Minas Gerais (FAPEMIG) pelo apoio financeiro.

\section{LITERATURA CITADA}

AGRIANUAL - 98, Alho: mercado e perspectivas. São Paulo: FNP consultoria, 1998. p.106110 .

BARNI, V.; GARCIA, S. Comportamento do alho Quitéria isento do Vírus do Estriado Amarelo em diferentes condições de cultivo. Hortisul, Pelotas, v. 3, n. 1, p. 15-19, 1994.

BERTONI, G.; MORARD, P.; SOUBIEILLE, C.; LLORENS, J.M. Growth and nitrogen nutrition of garlic (Allium sativum L.) during bulb development. Scientia Horticulturae, v. 50, n. 2, p. 187-195, 1992.

BHOJWANI, S.S.; COHEN, D.; FRY, P.R Production of virus-free garlic and field performance of micropropagated plants. Scientia Horticulturae, v. 18, n. 1, p. 39-43, 1982.

CÂMARA, F.A.A. Obtenção de plantas de alho (Allium sativum L.) a partir de meristemas $e$ microbulbificação “in vitro". Lavras:ESAL, 1988. 55 p. (Tese mestrado).

CARVALHO, M.G. de; SHEPPERD, R.J.; HALL, D.W. Decréscimo da produtividade do alho como resultado da reinfecção pelo "Garlic Yellow Stripe Virus”. Fitopatologia Brasileira, Brasília, v. 6, n. 3, p. 525-526, 1981.

COMISSÃO DE FERTILIDADE DO SOLO DE MINAS GERAIS. Recomendações para uso de corretivos e fertilizantes em Minas Gerais, 4o aproximação, Lavras, 1989. 76 p.

CONCI, V.C.; NOME, S.F. Virus-free garlic (Allium sativum L.) obtained by thermoterapy and meristem-tip culture. Journal of Phytopatology, v. 32, n. 3, p. 186-192, 1991.
CONCI, V.C.; NOME, S.F.; MILNE, R.G. Filamentous viruses of garlic in Argentina. Plant Disease, v. 76, n. 6, p. 594-596, 1992.

DANIELS, J.; CALDAS, L.S.; KITAJIMA, E.W. Plantas de alho (Allium sativum L.) supostamente sadias obtidas por cultura de meristemas de bulbilhos infectados por vírus. Fitopatologia Brasileira, Brasília, v. 3, n. 1, p. 82, 1978.

DIJK, P.V. Survey and characterization of potyviruses and their strains of Allium species. Netherlands Journal of Plant Pathology, v. 99, p. 1-48, 1993.

DUSI, A.N.; FAJARDO, T.V.M.; CUPERTINO, F.P. Serological identification of garlic (Allium sativum, L.) in Brazil. Fitopatologia Brasileira, Brasília, v. 19, p. 298, 1994.

EMPRESA BRASILEIRA DE PESQUISA AGROPECUÁRIA. Cultivo do alho. Brasília: CNPH, 1984. 16 p. (Instrução Técnica n. 2).

FAO (Roma, Italy). Agricultural production, primary crops - garlic. Disponível em http:// www.fao.org. Consultado em 11 de nov. de 1998.

FERREIRA, F.A. Análise do crescimento de quatro cultivares de alho (Allium sativum L.). Viçosa: UFV, 1972. 41 p. (Tese mestrado).

FONTES, P.C.R. Efeito de cinco épocas de plantio sobre o crescimento e produção do alho (Allium sativum L.), cultivar Amarante. Viçosa: UFV, 1973. 47 p. (Tese mestrado).

GARCIA, A.; DANIELS, J.; PETERS, J.A.; CASTRO, L.A.S. Sensibilidade de genótipos de alho (Allium sativum L.) à reinfecção por vírus. IN: CONGRESSO IBEROAMERICANO DE HORTICULTURA, 1., 1992, Montividéu. Resumos... Montividéu: CLAH/SOB, 1992.p. 32.

GARCIA, A.; PETERS, J.A.; CASTRO, L.A.S. de. Formação de estoques pré-básicos de alhosemente e estudo da sensibilidade da cultura à infecção por vírus. Hortisul, Pelotas, v. 1, n. 1, p. 42-44, 1989.

GIBBS, A.; HARRISON, B. Plant Virology: The principles, New York: Buffer and Turner, 1979. 292 p.

GRAICHEN, K.; KROMAT, H.; MEYER, U. Effect of virus infection on the yield performance of the garlic, cultivar Thuringer. Gartenbau, v. 35, n. 9, p. 266-267, 1988.

HWANG, J.M.; ANH, I.O.; CHOI, J.K. Studies on the production of virus-free plant through tissue culture in garlic (Allium sativum L.). The Research Reports of the Office Rural Development Korea, v. 25, n. 1, p. 22-30, 1983.

IBGE (Rio de Janeiro, RJ). Informações estatísticas, produção agrícola - alho. Disponível em http://www.sidra.ibge.gov.br. Consultado em 11 de nov. de 1998.

LITTLE, T.M.; HILLS, F.J. Agricultural Experimentation, New York: John Willey and sons, 1978. 350 p.

MANN, L.K. Anatomy of the garlic bulb and factors affecting bulb development. Hilgardia, V. 21, n. 8, p. 195-251, 1952.

MARSCHNER, H. General introduction to the mineral nutrition of plants. In: LAUCHLI, A.; BIELESKI, R.L. Inorganic plant nutrition, Berlin: Springer-Verlag, 1983. p. 5-60. 
MESSIAEN, C.M.; YOUCEF-BENKADA, M.; BEYRIES, A. Rendiment potentiel et tolérance aux virus chez l'ail (Allium sativum L.). Agronomie, v. 1, n. 9, p. 759-762, 1981.

MOSELLA, C.H.L.; FERNANDEZ, M.R. Cultivo in vitro del ajo (Allium sativum L.), tipo Rosado. Simiente, v.55, n.2, p.60-63, 1985.

NOGUEIRA, I.C.C. Efeitos do parcelamento do adubação nitrogenada sobre as características morfológicas, fisiológicas e produção do alho (Allium sativum L.), cultivar juréia. Lavras: ESAL, 1979. 64 p. (Tese mestrado).

OLIVEIRA, G.D.; FERNANDEZ, P.D.; SARRUGE, J.R.; HAAG, H.P. Nutrição mineral de hortaliças. Extração dos macronutrientes pelas hortaliças. O Solo, Piracicaba, v. 63, n. 1, p. 7-12, 1971.

PAIVA, E.; KITAJIMA, E.W. Doenças provocadas por vírus e por patógenos que causam sintomas semelhantes às viroses. Informe Agropecuário, Belo Horizonte, v. 11, n. 122, p. 29-36, 1985.
QUAK, F. Meristem culture and virus-free plants. In: REINERT, J. ; BAJAJ. Y.P. Applied and fundamental aspects of plant cell, tissue and organ culture. New York: Spring Verlag, 1977. p. 589-615.

RESENDE, F.V.; SOUZA, R.J. de; PASQUAL, M. Comportamento, em condições de campo, de clones de alho obtidos por cultura de meristema. Horticultura Brasileira, Brasília, v. 13, n.1, p. 44-46,1995.

SALISBURY, F.B.; ROSS, C.W. Plant physiology. 3 ed. Belmont: Wadsworth, 1985. 540 p.

SILVA, N.; OLIVEIRA, G.D.; VASCONCELOS, E.F.C.; HAAG, H.P. Nutrição mineral de hortaliças. Absorçao de nutrientes pela cultura do alho. In: HAAG, H.P. ; MINAMI, K. Nutrição mineral em hortaliças. Campinas: Fundação Cargill, 1981. p. 241-256.
WALKEY, D.G.A.; ANTILL, D.N. Agronomic evaluation of virus-free and virus-infected garlic (Allium sativum L.). Journal of Horticultural Science, v. 64, n. 13, p. 53-60, 1989.

WALKEY, D.G.A.; WEBB, M.J.W.; BOLLAND, C.I.; MILLER, A. Production of virus-free garlic (Allium sativum L.) and shallot (Allium ascalonicum L.) by meristem-tip culture. Journal of Horticultural Science, v. 62, n. 2, p. 211-220, 1987.

WERNER, R.A. Manejo pós-colheita do alho. Informe Agropecuário, Belo Horizonte, v. 12, n. 142, p. 46-49, 1986.

ZINK, F.W. Rate of growth and nutrient absorption of late garlic. Proceedings of the Americam Society of Horticultural Science, v. 83, p. 579584, 1963. 